Indonesian Journal of Biotechnology, December 2015

Vol. 20, No. 2, pp.174-181

\title{
Detection and identification of adherence genes of intestinal-origin Lactobacillus and Pediococcus strains grown on gastric mucin in vitro
}

\author{
Widodo $^{1,2^{*}}$, Sri Lestari ${ }^{2}$, and Widya Asmara ${ }^{2,3}$
}

${ }^{1}$ Faculty of Animal Science, Universitas Gadjah Mada, Yogyakarta, Indonesia

${ }^{2}$ Research Centre for Biotechnology, Universitas Gadjah Mada, Yogyakarta, Indonesia

${ }^{3}$ Faculty of Veterinary Medicine, Universitas Gadjah Mada, Yogyakarta, Indonesia

\begin{abstract}
One of the primary selection criteria for potential probiotics is the ability to adhere to the host gastrointestinal tract. This study evaluated the in vitro adhesion ability on gastric mucin of two Lactobacillus casei strains (AP and AG) and two Pediococcus acidilactici strains (BE and BK), and identified the corresponding genes responsible for adherence. Adhesion assays were performed in 96-well polystyrene microtiter plates using gastric mucin from porcine stomach as the matrix. An in vitro study on gastric mucin revealed that lactobacilli had a greater adherence ability compared with pediococci strains. The potential adherence genes were investigated using polymerase chain reaction (PCR) technology. Using specific primers, PCR studies amplified 150 base pairs of a potential mub gene and 161 base pairs of a potential ef-Tu gene, but no amplified bands for potential map and bac genes were obtained. Sequence comparisons showed that the 150 and 161 amplified base pairs were respectively homologous to the mub of Pediococcus acidilactici and ef-Tu genes of Lactobacillus paracasei. We concluded that the adherence ability of two strains of Lactobacillus casei (AP and AG) and two strains of Pediococcus acidilactici (BE and BK) on gastric mucin is in accordance with the presence of $e f-T u$ and $m u b$ genes. High level attachment in lactobacilli is likely to correlate with the $e f-T u$ gene, which is a lactobacilli-specific adhesive gene.
\end{abstract}

Keywords: Adherence genes, intestinal origin, Lactic Acid Bacteria

\section{Introduction}

Bacterial strains for probiotics have been isolated from different sources; and one of the best sources is the gastrointestinal tract (GIT) of humans (Margolles et al., 2009). It has previously been reported that the rapid development of probiotics inside the human GIT is due to the consumption of human milk oligosaccharides (HMOs) (Favier et al., 2003). In order to function as probiotics, bacterial strains must have specific criteria. One of the important criteria is the ability of strains to attach to gut epithelial tissues and colonize the GIT (Collins et al, 1998; Dunne et al., 1999).

\section{*Corresponding author:}

Widodo

Faculty of Animal Science, Universitas Gadjah

Mada, Yogyakarta, Indonesia

Email: widodohs@ugm.ac.id
Adherence to the mucosa of the digestive tract allows probiotic colonization, immune stimulation and competition with pathogens by means of competition for receptor sites at the surface of the host intestine (Lahtinen and Ouwehand, 2009). Probiotic colonization of intestinal surfaces prevents the presence of pathogens, and consequently protects the host from bacterial infection (Brassart and Schiffrin, 2007).

The ability to bind to the GIT, along with survival in the intestine, is generally considered to be the main characteristics observed in probiotics. Previous studies on the molecular basis of adhesion have been conducted mainly based on the in vitro adhesion of probiotics cells to adhesion models such as cell lines (Caco-2 and HT-29) or mucus preparations (Ljungh and Wadstrom, 2009). A number of adhesion 
proteins have been studied and characterized, including mucus-binding proteins (Mub) (Roos and Jonsson, 2002), mucus adhesion promoting protein (MapA) (Ramiah et al., 2007), anchorless multifunction proteins elongation factor $\mathrm{Tu}(\mathrm{Ef}-\mathrm{Tu})$ (Greene and Klaenhammer, 1994; Ramiah et al., 2007) and surface layer proteins (Boot et al., 1993; Vidgren et al., 1992). According to Ljungh and Wadstrom (2009), proteins involved in the adhesive mechanism can be separated into five classes: anchorless housekeeping proteins, surface layer proteins, LPXTG-motif proteins, transporter proteins, and other proteins. The corresponding genes for these proteins has also been investigated, including ef-Tu, bac, mapA, $m u b, m s a$, and $\operatorname{slpA}$ (Turpin et al., 2012). The binding capacity of probiotics varies between strains, and could be due to differential expression of the corresponding genes. At least 20 genes were reported to be functionally important in the binding of Lactobacillaceae to the digestive tract (Turpin et al., 2012).

Widodo et al. (2012a; 2012b) successfully identified Lactobacillus casei strains AF, AP, and AG and Pediococcus acidilactici strains $\mathrm{AA}, \mathrm{BE}$, and $\mathrm{BK}$ in the feces of Indonesian infants consuming breast milk. Of these strains, Lactobacillus casei strains AP and AG, and Pediococcus acidilactici strain BE were able to degrade prebiotic inulin (Widodo et al., 2012b; 2014) and showed potential as probiotics. However, the ability of these strains to attach to the GIT has never been investigated. This study was carried out to investigate the adherence ability of selected strains in vitro, and to identify adherence genes that might correlate with the ability to attach to intestinal surfaces.

\section{Materials and Methods}

Bacterial strains and adherence assays in vitro

Lactobacillus casei strains AP and AG and Pediococcus acidilactici strains BE and BK were obtained from previous experiments (Widodo et al., 2012a; 2012b). Bacterial strains were routinely cultured at $37^{\circ} \mathrm{C}$ in de Man
Rogosa Sharpe (MRS, Merck) media. In vitro adherence ability assay was carried out according to Sanchez et al. (2010) and Roos and Jonsson (2002) with modification. Adhesion assays were performed in 96-well polystyrene microtiter plates (Corning) using gastric mucin from porcine stomach (Sigma) as the matrix.

\section{Genomic DNA extraction}

Genomic DNA was extracted from 1.5 $\mathrm{mL}$ of overnight cell culture, suspended in 400 $\mu$ LSET buffer (75 mM NaCl, 25 mM EDTA, 20 $\mathrm{mM}$ Tris- $\mathrm{HCl}, \mathrm{pH} 7.5)$ containing lysozyme $(30 \mathrm{mg} / \mathrm{mL})$. The solution was mixed by inverting the tube, and incubated at $37^{\circ} \mathrm{C}$ for $1 \mathrm{~h}$. Fifty (50) $\mu \mathrm{L}$ of SDS solution $(10 \%)$ was added and followed by incubation at $65{ }^{\circ} \mathrm{C}$ for $1 \mathrm{~h}$. After $1 \mathrm{~h}$ of incubation, $167 \mu \mathrm{L}$ of $\mathrm{NaCl}$ solution (5M) was added and incubation was prolonged for another $1 \mathrm{~h}$. DNA was separated from cellular debris with $400 \mu \mathrm{L}$ chloroform, incubated at room temperature for $10 \mathrm{~min}$, and then centrifuged at 13000 rpm for $10 \mathrm{~min}$. The top aqueous phase was transferred to a new Eppendorf tube and the DNA was precipitated overnight with isopropanol at $-20^{\circ} \mathrm{C}$. Precipitated DNA was harvested by centrifugation at $13000 \mathrm{rpm}$ for 10 min, washed with $500 \mu \mathrm{L}$ ethanol (70\%), and resuspended in Tris-EDTA (TE) buffer. Agarose gel electrophoresis was carried out on $0.8 \%$ agarose gel in TAE buffer at $80 \mathrm{~V}$ for $1 \mathrm{~h}$. Size was calculated using a $1 \mathrm{~kb}$ DNA Ladder (Promega, USA).

\section{DNA amplification}

Amplification of the gene of interest was carried out using PCR with primers designed according to Ramiah et al. (2007), as presented in Table 1. The glyceraldehyde 3-phosphate dehydrogenase (GDPH ) gene was used as the standard reference gene. Gene amplification was performed using a PCR thermal cycler, with the protocol set as follows: denaturation at $95^{\circ} \mathrm{C}$ for $30 \mathrm{~s}$, annealing at $56^{\circ} \mathrm{C}$ for 30 s, elongation at 72 ${ }^{\circ} \mathrm{C}$ for $45 \mathrm{~s}$ (30 cycles), and a final extension 
Table 1. Primers for PCR amplification.

\begin{tabular}{|c|c|c|}
\hline Primers & Sequence $5^{\prime}$ to $3^{\prime}$ & Amplicon (base pairs) \\
\hline EFTu & $\begin{array}{l}\text { F (TCGATGCTGCTCCAGAAGAAA) } \\
\text { R (TGGCATAGGACCATCAGTTGC) }\end{array}$ & 161 \\
\hline$M u b$ & $\begin{array}{l}\text { F (GTAGTTACTCAGTGACGATCAATG) } \\
\text { R (TAATTGTAAAGGTATAATCGGAGG) }\end{array}$ & 150 \\
\hline$B a c$ & $\begin{array}{l}\text { F (GACATTTACATTGAGTAGGAACTAG) } \\
\text { R (GTAACCCCATTACCATAGTATTTAC) }\end{array}$ & 147 \\
\hline Map & $\begin{array}{l}\text { F (TAATTGTAAAGGTATAATCGGAGG) } \\
\text { R (TGGATTCTGCTTGAGGTAAG) }\end{array}$ & 156 \\
\hline GDPH & $\begin{array}{l}\text { F (ACTGAATTAGTTGCTATCTTAGAC) } \\
\text { R (GAAAGTAGTACCGATAACATCAGA) }\end{array}$ & 140 \\
\hline
\end{tabular}

at $72{ }^{\circ} \mathrm{C}$ for $10 \mathrm{~min}$. Amplified bands were resolved by electrophoresis in $1.6 \%(\mathrm{w} / \mathrm{v})$ agarose gels and visualized using ethidium bromide staining.

\section{DNA sequencing and phylogenetic analysis}

The amplified DNA was sequenced using an Applied Biosystems 3730-XL Analyzer at $1^{\text {st }}$ Base Sequencing, Kuala Lumpur, Malaysia. The resulting sequences were used to search the National Centre for Biotechnology Information (NCBI) database using the Basic Local Alignment Search Tool (BLAST) algorithm. The isolates were identified on the basis of the sequences that produced the best match $(>97 \%)$. Molecular Evolutionary Genetics Analysis (MEGA) 6.0 was used to construct a phylogenetic tree of the sequences based on the neighbor-joining algorithm (Saitou and Nei, 1987).

\section{Results and Discussion}

Some of the beneficial effects exerted by probiotics are triggered by the interaction with the gastrointestinal (GIT) mucosa. As such, adhesion to the GIT mucosa is the most crucial factor contributing to successful probiotic colonization in upper intestinal regions (Tannock, 1992). Mucosal colonization by probiotics can be found both in the mucus layer and epithelial cells (Brassart and Schiffrin, 2007). The epithelial cells of the intestine are covered by a protective layer of mucus, which is a complex mixture of glycoproteins and glycolipids, with large glycoprotein mucin being the main component. Complexes of glycoproteins in the mucus layer prevent the host from harmful antigens and pathogens, and promote luminal motility (McGroarty, 1993; Van Tassell and Miller, 2011). Therefore, adhesion to this mucus is required for probiotic interaction to occur with the host and to elicit a response (Van Tassell and Miller, 2011). Given that mucin is the main component of the mucus layer, adhesion assays were performed in vitro using gastric mucin from porcine stomach (Sigma) as the matrix. The use of in vitro models, as opposed to in vivo ones, was due to the complexity of in vivo studies.

Table 2 shows that every strain had a different ability to adhere to gastric mucin in vitro. Lactobacilli strains (AP and AG) had a greater adherence ability compared with pediococci strains (BE and BK). The percentage of adhering cells of strains $\mathrm{AP}$, $\mathrm{AG}, \mathrm{BE}$, and $\mathrm{BK}$ on mucus after 60 minutes were $49.25 \pm 0.35 \%, 53.03 \pm 0.48 \%, 36.80 \pm 0.46 \%$, and $23.96 \pm 0.32$, respectively.

The high adhesion capability in lactobacilli presented here is in agreement with previous findings. A study by Drury et al. (2011) demonstrated the ability of indigenous probiotic Lactobacillus strains Lp9 and Lp91 to adhere to Caco-2 and HT-29 colonic adenocarcinoma human intestinal epithelial cell lines in vitro. They reported that Lactobacillus Lp91 was the most adhesive strain to HT-29 and Caco-2 cell lines with adhesion values of $12.8 \%$ and $10.2 \%$, respectively. Another study by 
Widodo et al.

Table 2. In vitro adhesion assays of four probiotic strains on mucin.

\begin{tabular}{|c|c|c|c|}
\hline \multirow[t]{2}{*}{ Strains } & \multicolumn{2}{|c|}{$\begin{array}{l}\text { Time of incubation } \\
\text { (minutes) }\end{array}$} & \multirow{2}{*}{$\begin{array}{l}\text { Percentage } \\
\text { of adhering } \\
\text { cells after } 60 \\
\text { minutes }(\%)\end{array}$} \\
\hline & 0 & 60 & \\
\hline $\mathrm{AP}$ & $199.5 \pm 0$. & $25 \pm$ & $49.25 \pm 0.35$ \\
\hline AG & $177.25 \pm 0.50$ & $94.00 \pm 0.82$ & 53.0 \\
\hline $\mathrm{BE}$ & $146.75 \pm 0.50$ & $54.00 \pm 0.82$ & $36.80 \pm 0.46$ \\
\hline $\mathrm{BK}$ & $144.00 \pm 0.82$ & $34.50 \pm 0.58$ & $23.96 \pm 0.32$ \\
\hline
\end{tabular}

AP: Lactobacillus casei strain AP; AG: Lactobacillus casei strain AG; BE: Pediococcus acidilactici strain BE; and BK: Pediococcus acidilactici strain BK.

Lewandowska et al. (2005) demonstrated an adhesion yield of $33.81 \%$ for Lactobacillus rhamnosus GG, and 3.89\% for Lactobacillus helveticus, to Caco-2 cells. Meanwhile, a study by $\mathrm{Xu}$ et al. (2009) demonstrated a less than $10 \%$ adhesion yield of Pediococcus acidilactici KACC 12307 to Caco-2 cells.

The high adherence ability of L. casei strains AP and AG in vitro, as presented in Table 2 , is unlikely affected by the presence of the mub gene because the identified mub gene in this study is highly homologous with the relevant genes from non-L. casei species, namely $P$. acidilactici and L. plantarum.

a

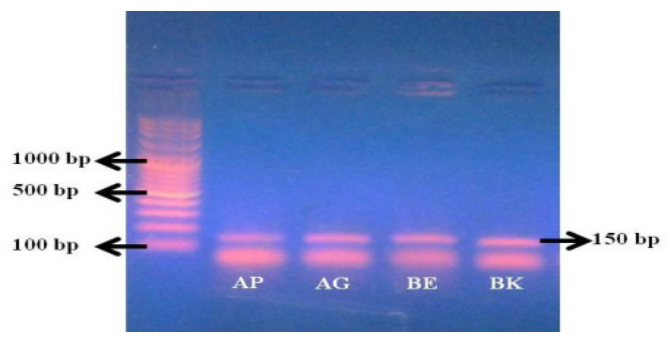

C

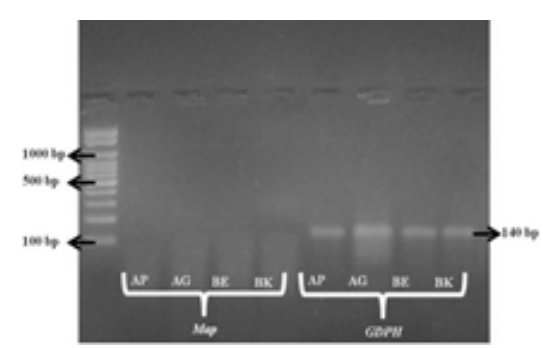

I.J. Biotech, Vol. 20, No. 2

Mub was the first Lactobacillus adhesion protein shown to contain the same domain organization as that of adhesins from other Gram-positive bacteria (Ramiah et al., 2007). Mub proteins have a high molecular weight (358 kDa) with approximately 200 amino acid long sequences and regions typical for other cell surface proteins in Gram-positive bacteria, such as an N-terminal secretion signal peptide, a cell wall anchoring motif (LPXTG), a putative membrane-spanning region and a cell-membrane anchor. The Mub gene is expressed 80-140-fold more in the presence of mucin, but is suppressed 7-30-fold under normal gut physiological conditions containing bile and pancreatin (Ramiah et al., 2009).

The ability of the four strains to adhere on gastric mucin in vitro (Table 1) might correlate with the presence of the ef-Tu gene (Figure 1). The Ef-Tu protein facilitates the transfer of aminoacyl-tRNA to the A-site of ribosomes during protein synthesis (Gaucher et al., 2001). However, the Ef-Tu protein also binds to mucin and mediates bacterial colonization of human intestinal cells and mucus.

b

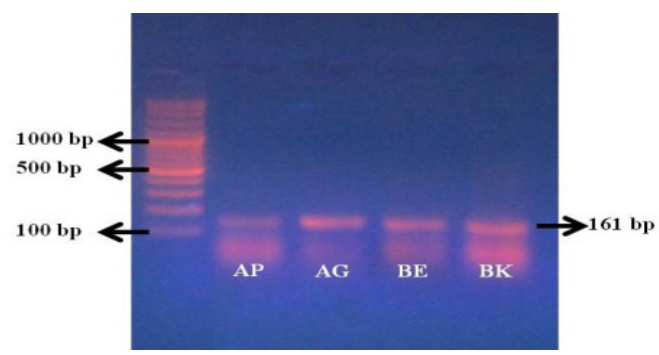

d

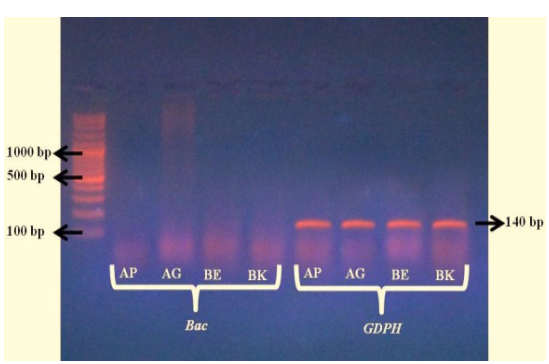

Figure 1. Amplification of (a) mub, (b) ef-Tu, (c) map, and (d) bac genes. 

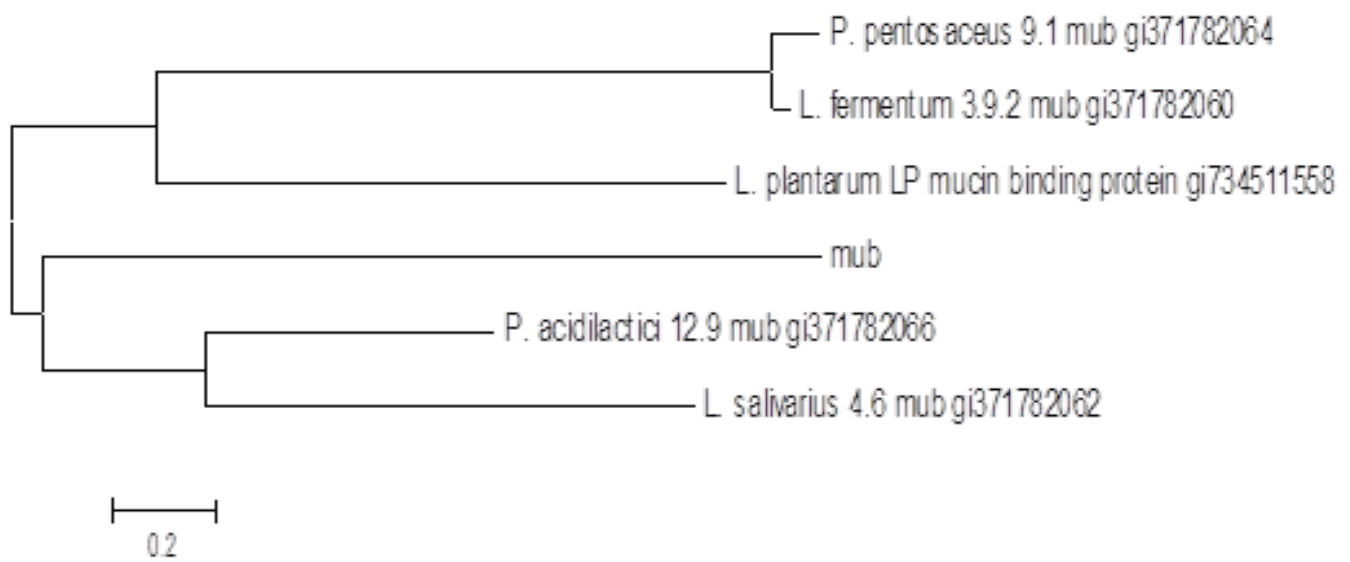

Figure 2. Phylogenetic tree showing the genetic relationship of the mub gene of the selected strains with other mub genes from genera Lactobacillus and Pediococcus based on 16S rRNA sequences.

The binding of ef-Tu to mucus or cells has been proposed to have a role in gut homeostasis (Granato et al., 2004). The ef-Tu gene is expressed 33-100 times higher in media containing mucus, but is not affected by bile or pancreatin concentrations (Ramiah et al., 2009). This may indicate an interplay between different mechanisms regulating adhesin expression to adapt to particular environments.

Figure 1 shows that the $m u b$ and ef-Tu genes were detected in all of the strains (AP, $\mathrm{AG}, \mathrm{BE}$, and $\mathrm{BK})$, as seen with the presence of amplified 150 and 161 base pair (bp) sequences, respectively, suggesting that all the strains carry the $e f-T u$ and mub genes. In contrast, the other two genes (map and bac) were not detected in any of the strains, indicating that none of the four strains carry these genes (Figure 1).

Further elaboration of the amplified 150 bp was carried out. The amplified $150 \mathrm{bp}$ was isolated, purified, and sequenced. The sequence comparison of the selected bands with a relevant database showed that the amplified $150 \mathrm{bp}$ was highly homologous with the partial mub gene of Pediococcus acidilactici 12.9 (Figure 2). Meanwhile, the amplified band of $161 \mathrm{bp}$ of the candidate ef-Tu gene was also investigated. The amplified $161 \mathrm{bp}$ bands were sequenced, and the sequence data were compared with a relevant database in silico. The sequence comparison showed that the amplified $161 \mathrm{bp}$ band showed high similarity with the sequence of the ef-Tu gene from Lactobacillus paracasei strain LBS3 (Figure 3). Figure 3 shows that the ef-Tu gene was genetically close to other ef-Tu genes from lactobacilli, suggesting that the higher level of adherence on lactobacilli than on pediococci is in line with the presence of ef-Tu genes.

Based on molecular identification, this study also reports that none of the four strains carry the map and bac genes (Figure 1). A mucus adhesion promoting protein (map) is a cell surface protein with a molecular mass of $26 \mathrm{kDa}$ and theoretical pI of 9.7 (Ramiah, 2007). The mapA gene is upregulated 6-8fold when incubated in the presence of mucin and up to 25-fold when exposed to physiological concentrations of pancreatin and bile compared with MRS grown controls (Ramiah et al., 2009). A previous study also found that the map A gene is significantly down-regulated in the presence of cysteine, suggesting that cysteine is an effector molecule that represses transcription of the mapA gene. Similar to the map gene, none of the tested strains carry the bac gene. According to Ramiah (2009), the bac gene is highly detected in the genome of Lactobacillus plantarum 423 in ileum and cecum tissue samples. These data suggest that not all lactic acid bacteria have the bac gene, and the presence of this gene is tissue-specific. 


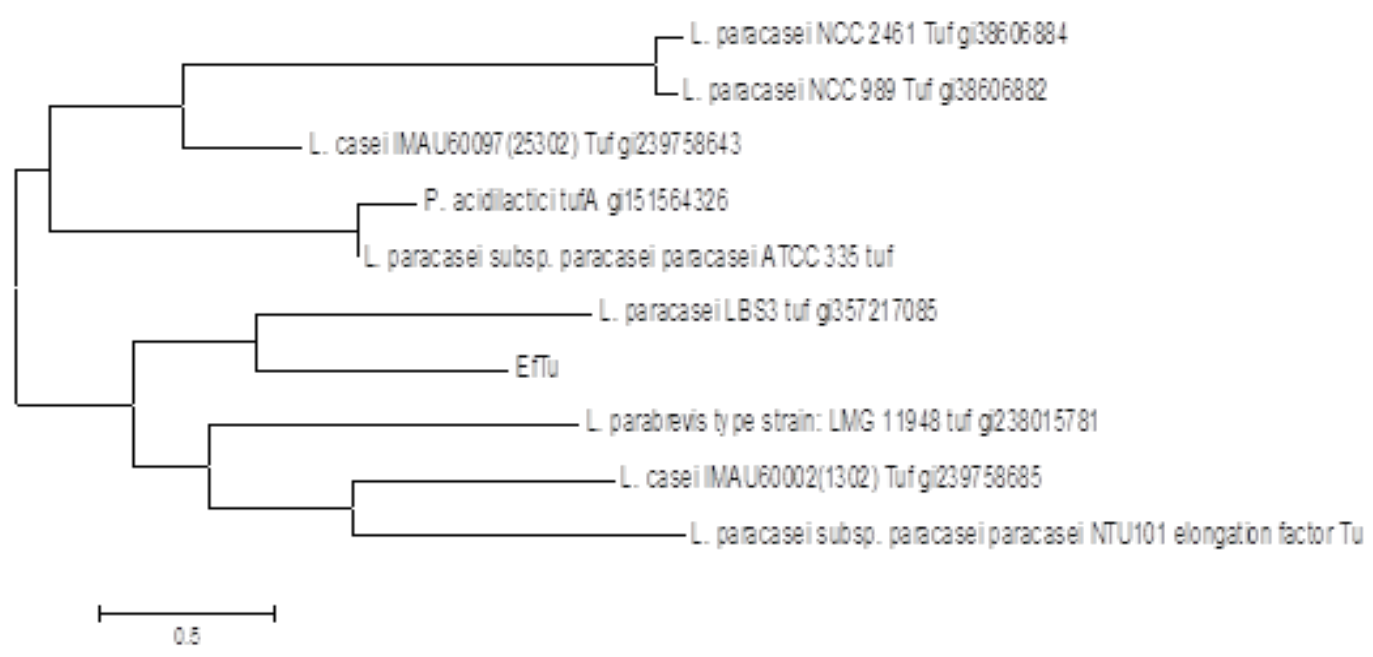

Figure 3. Phylogenetic tree showing genetic relationship of the ef-Tu gene of the selected strains with other ef-Tu genes from genera Lactobacillus and Pediococcus based on 16S rRNA sequences.

\section{Conclusion}

The in vitro adherence ability of two strains of Lactobacillus casei (AP and AG) and Pediococcus acidilactici (BE and BK) is in accordance with the presence of ef-Tu and mub genes but not map and bac genes. High level attachment in lactobacilli is likely to correlate with the ef-Tu gene, which is a lactobacilli-specific adhesive gene.

\section{Acknowledgements}

The authors would like to thank the Indonesian Ministry for Research and Higher Education for providing the research grants.

\section{References}

Brassart, D. and Schiffrin, E. J. 2007 The use of probiotics to reinforce mucosal defence mechanism. Trends Food Sci. Tech.. 8: 321326. doi:10.1016/S0924-2244(97)01071-6

Boot, H. J., Kolen, C. P., van Noort, J. M. and Pouwels, P. H. 1993. S-layer protein of Lactobacillus acidophilus ATCC 4356: purification, expression in Eschericia coli and nucleotide sequence of the corresponding gene. J. Bacteriol. 175: 6089-6096.

Collins, R. L., Morsheimer, E. T., Shiffman, S., Paty, J. A., Gnys, M. and Papandonatos, G. D. 1998. Ecological momentary assessment in a behavioral drinking moderation training program. Exp. Clin. Psychopharmacol. 6: 306-315. http:// dx.doi.org/10.1037/1064-1297.6.3.306

Drury, L.J., Ziarek, J.J., Gravel, S., Veldkamp, C.T., Takekoshi, T., Hwang, S.T., Heveker, N., Volkman, B.F., dan Dwinell, M.B. 2011. Monomeric and dimeric CXCL12 inhibit metastasis through distinct CXCR4 interactions and signaling pathways. PNAS 108: 17655-17660.

Dunne, C., Murphy, L., Flynn, S., O'Mahoney, L., O'Halloran, S., Feeney, M., Morrissey, D., Thornton, G., Fitzgerald, G., Daly, C., Kiely, B., Quigley, E. M. M., O'Sullivan, G. C., Shanahan, F. and Collins, J. K. 1999. Probiotics: from myth to reality. Demonstration of functionality in animal models of disease and in human clinical trials. Antonie van Leeuwenhoek 76: 279-292.

Favier, C. F., de Vos, W. M. and Akkermans, A. D. L. 2003. Development of bacterial and bifidobacterial communities in feces of newborn babies. Anaerobe 9: 219-29. doi:10.1016/j.anaerobe.2003.07.001

Gaucher, E. A., Miyamoto, M. M. and Benner, S. A. 2001. Function structure analysis of proteins using covarion based evolutionary approaches: elongation factors. PNAS 98: 548-552. 
Granato, D., Bergonzelli, G. E., Pridmore, R. D., Marvin, L., Rouvet, M. and Corthesy-Theulaz, I. E. 2004. Cell surfaceassociated elongation factor $\mathrm{Tu}$ mediates the attachment of Lactobacillus johnsonii NCC533(La1) to human intestinal cells and mucins. Infect. Immun. 72: 2160-2169.

Greene, J. D. and Klaenhammer, T. R. 1994. Factors involved in adherence of lactobacilli to human Caco-2 cells. Appl. Environ. Microbiol. 60: 4487-4494.

Lahniten, S. and Ouwehand, A. 2009. Adhesion to Intestinal Mucus and Epithelium by Probiotics. In: Handbook of Probiotics and Prebiotics. Lee, Y. K. and Salminen, S. (eds.). John Wiley and Sons Inc. Hoboken, New Jersey.

Lewandowska, M., Olejnik, A., Neumann, M., Krêpulec, A., Piotrowska, J., Teresiak, A., Grajek, W. 2005. Comparative in vitro study on the adhesion of probiotic and pathogenic bacteria to different human intestinal cell lines. Biotechnologia 2: 215-233.

Ljungh, A. and Wadstrom, T. 2009. Lactobacillus Molecular Biology: From Genomics to Probiotics. Caister Academic Press. Norfolk, UK.

Margolles, A., Mayo, B. and Ruas-Madiedo, P. 2009. Screening, identification and characterization of Lactobacillus and Bifidobacterium strains. In: Handbook of Probiotics and Prebiotics. Lee, Y. K. and Salminen, S. (eds.). John Wiley and Sons. Hoboken, New Jersey.

McGroarty, J. A. 1993, Probiotic use of lactobacilli in the human female urogenital tract. FEMS Immun. Med. Microbiol. 6: 251264. http://dx.doi.org/10.1111/j.1574695X.1993.tb00337.x

Ramiah, K., van Reenen, C. A. and Dicks, L. M. 2009 Expression of the mucus adhesion gene $m u b$, surface layer protein Slp and adhesion-like factor ef-Tu of Lactobacillus acidophilus ATCC 4356 under digestive stress conditions, as monitored with real-time PCR. Probiotic Antimicrob. Prot. 1: 91-95. DOI: 10.1007/s12602-009-9009-8
Ramiah, K., van Reenen, C. A. and Dicks, L. M. 2007. Expression of the mucus adhesion genes Mub and MapA, adhesion-like factor EF-Tu and bacteriosin gene plaA of Lactobacillus plantarum 423, monitored with real-time PCR. Int. J. Food Microbiol., 116: $405-409$.

Roos, S. and Jonsson, H. 2002. A highmolecular-mass cell-surface protein from Lactobacillus reuteri 1063 adheres to mucus components. Microbiology 148: 433-442.

Saitou, Nand Nei, M.1987Theneighborjoining method: a new method for reconstructing phylogenetic trees. Mol. Biol. Evol. 4: 619629.

Sanchez, B., Saad, N., Schmitter, J-M., Bressollier, P. and Urdaci, M. C. 2010. Adhesive properties, extracellular protein production, and metabolism in the Lactobacillus rhamnosus GG strain when grown in the presence of mucin. J. Microbiol. Biotechnol. 20: 978-984.

Tannock, G. W. (992. Lactic Microflora of Pigs, Mice and Rats. In: The Lactic Acid Bacteria. Volume 1: The Lactic Acid Bacteria in Health and Disease. Wood, B. J. B. (ed.). Elsevier Applied Science Publishers. London, UK. DOI: 10.1007/978-1-4615-3522-5_2

Turpin, W., Humblot, C., Noordine, M-L., Thomas, M. and Guyot, J-P. 2012. Lactobacillaceae and cell adhesion: genomic and functional screening. PLoS One 7 e38034. http://dx.doi.org/10.1371/ journal.pone.0038034

Van Tassell, M. L. and Miller, M. J. 2011 Lactobacillus adhesion to mucus. Nutrients 3: 613-636. doi:10.3390/nu3050613

Vidgren, G., Palva, I., Pakkanen, R., Lounatmaa, K. and Palva, A. 1992. S-layer protein gene of Lactobacillus brevis: cloning by polymerase chain reaction and determination of the nucleotide sequence. J. Bacteriol. 174: 7419-7427.

Widodo., Taufiq, T. T., Aryati, E., Kurniawati, A. and Asmara, W. 2012a. Human origin Lactobacillus casei isolated from Indonesian infants demonstrating 
potential characteristics as probiotics in vitro. Indon. J. Biotechnol. 17: 79-89.

Widodo., Anindita, N. S., Taufiq, T. T. and Wahyuningsih, T. D. 2012b. Identification of Pediococcus strains isolated from feces of Indonesian infants with in vitro capability to consume prebiotic inulin and to adhere on mucus. Indon. J. Biotechnol. 17: 132-143.

Widodo., Anindita, N. S., Taufiq, T. T. and Wahyuningsih, T. D. 2014. Evaluation of two Lactobacillus strain as probiotics with emphasis in utilizing prebiotic inulin as energy source. Int. Res. J. Microbiol. 5: 33-40. DOI: http:/dx.doi.org/10.14303/ irjm.2014.016.

Xu, H., Jeong, H.S., Lee, H.Y. and Ahn, J. 2009. Assessment of cell surface properties and adhesion potential of selected probiotic strains. Appl. Microbiol. Lett. 49: 434-442. 